\title{
Evaluation of Thyroid Nodules in Children and Adolescents: Multicenter Study in Turkey
} Çocuk ve Adolesanlarda Tiroid Nodüllerinin Değerlendirilmesi:
Türkiyede Çok Merkezli Çalışma

\author{
Emel Hatun Aytaç Kaplan* (0000-0002-8385-4049), Aydilek Dağdeviren Çakır** (0000-0001-7136-9241), İhsan \\ Esen $^{\star \star \star}$ (0000-0003-1700-6778), Emine Demet Akbaş ${ }^{\star \star \star \star}$ (0000-0002-5746-6835), Eda Çelebi Bitkin ${ }^{\star \star \star \star \star ~}(0000-0002-$ \\ 6586-7305), Nesibe Akyürek ${ }^{\star \star \star \star \star \star}(0000-0003-3443-0829)$, Bahar Özcabı ${ }^{\star \star \star \star \star \star \star ~}(0000-0002-1089-9326)$, Suna Kılı \\ nç ${ }^{\star \star \star \star \star \star \star \star}(0000-0002-0760-2640)$, Birgül Kırel ${ }^{\star \star \star \star \star \star \star \star \star}(0000-0002-8313-5677)$, Deniz Okdemir ${ }^{\star \star \star}(0000-0003-3618-8167)$, \\ Olcay Evliyaoğlu** (0000-0003-4851-8637), Mehmet Keskin* (0000-0002-5544-8991) \\ *Gaziantep Univercity Faculty of Medicine, Departmant of Pediatric Endocrinology, Gaziantep, Turkey \\ ${ }^{\star *}$ Istanbul Univercity Cerrahpaşa-Cerrahpaşa Faculty of Medicine, Departmant of Pediatric Endocrinology, İstanbul, Turkey \\ ${ }^{\star \star \star *}$ Fırat Univercity Faculty of Medicine, Departmant of Pediatric Endocrinology, Elazığ, Turkey \\ ${ }^{\star * * \star}$ Adana City Training and Research Hospital, Clinic of Pediatric Endocrinology, Adana, Turkey

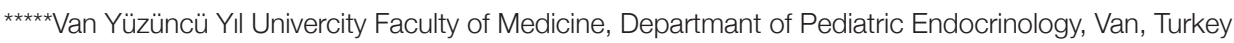 \\ ${ }^{* * * \star * \star K o n y a ~ T r a i n i n g ~ a n d ~ R e s e a r c h ~ H o s p i t a l, ~ C l i n i c ~ o f ~ P e d i a t r i c ~ E n d o c r i n o l o g y, ~ K o n y a, ~ T u r k e y ~}$

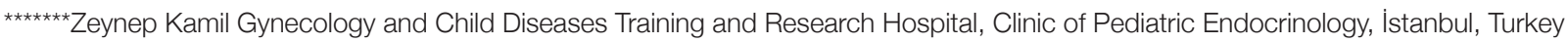 \\ ********Bağcllar Training and Research Hospital, Clinic of Pediatric Endocrinology, İstanbul, Turkey

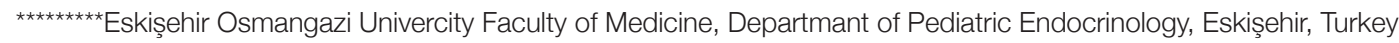

Keywords

Childhood, fine needle aspiration biopsy, thyroid, ultrasonography

\section{Anahtar kelimeler \\ Çocukluk çağı, ince iğne aspirasyon biyopsisi, tiroid, ultrasonografi}

Received/Geliş Tarihi : 27.06 .2021

Accepted/Kabul Tarihi : 23.10 .2021

DOI:10.4274/jcp.2021.43926

Address for Correspondence/Yazışma Adresi: Emel Hatun Aytaç Kaplan Ass. MD, Gaziantep Univercity Faculty of Medicine, Departmant of Pediatric Endocrinology, Gaziantep, TurkeyPhone: +90 5059397237 E-mail: emel_ctf@hotmail.com

\begin{abstract}
Introduction: Ultrasonography and fine needle aspiration biopsy are reliable diagnostic methods used to predict malignancy in thyroid nodules. They are useful in identifying patients for therapy or preventing unnecessary surgery.

Materials and Methods: The aim of this study was to compare clinical and ultrasonographic findings with fine needle aspiration biopsy and histopathological examination results in children with thyroid nodules. Retrospective study.

This multicentre study included pediatric patients with thyroid nodules, followed up between July 2002 and November 2019 in nine Turkish Pediatric Endocrinology Units. Clinical, ultrasonographic, cytological and histopathological findings (malignant or benign) were analyzed retrospectively. Fine needle aspiration biopsy findings were classified according to American Thyroid Association criteria.

Results: A total of 203 children were included, of whom $82.3 \%(n=167)$ were female. Mean \pm standard deviation age was 14.06 \pm 2.26 (range 3.7-19) years. Cytological diagnoses were: non-diagnostic or unsatisfactory $1.9 \%$; benign $59.6 \%$; atypia or follicular lesion of undetermined significance, suspicious for follicular neoplasm in 2.4\%; suspicious for malignancy $12.8 \%$; and malignant in $1.9 \%$. Surgery was performed in $59(29.1 \%)$ patients. In total $33(16.3 \%)$ patients were diagnosed with malignancy. In patients with benign fine needle aspiration biopsy results, malignancy was detected in $17.6 \%$ when they underwent surgery. Malignancy was present in $44.4 \%$ of the patients with cytologically determined atypia or follicular lesion of undetermined significance. The diagnostic accuracy of fine needle aspiration biopsy was $79 \%$.

Conclusion: This study is first multicentre study investigating thyroid nodules in children and adolescents in Turkey. In this population fine needle aspiration
\end{abstract}


biopsy has an important role in diagnosis, but ultrasonographic features of nodule should also be taken into consideration. Atypia or follicular lesion of undetermined significance may be of greater clinical significance than has previously been reported.

\section{$\ddot{O}_{z}$}

Giriş: Ultrasonografi ve ince iğne aspirasyon biyopsisi, tiroid nodüllerinde maligniteyi öngörmede kullanılan güvenilir tanı yöntemleridir. Doğru hastayı bulmada ve gereksiz ameliyatları önlemede faydalıdırlar. Bu çalışmanın amacı tiroid nodülü bulunan çocuklarda ince iğne aspirasyon biyopsisi ile klinik, ultrasonografik bulgular ve histopatolojik inceleme sonuçlarını karşılaştırmaktır. Gereç ve Yöntem: Bu çok merkezli çalışmada, Türkiye'den 9 farklı Pediatrik Endokrinoloji Ünitesinde Temmuz $2002-K a s ı m ~ 2019$ tarihleri arasında takip edilen tiroid nodüllü hastaların verileri incelendi. Tiroid nodüllü çocuk hastaların klinik, ultrasonografik, sitolojik ve histopatolojik bulguları (malign veya benign) retrospektif olarak incelendi. İnce iğne aspirasyon biyopsisi ile takip edilen hastaların bulguları Amerikan Tiroid Birliği'ne göre sınıflandırıldı.

Bulgular: Çalışmaya toplam 203 çocuk dahil edildi, hastaların \%82,3'ü (n=167) kadındı. Hastaların ortalama yaşı 14,06 $\pm 2,26$ yıl (dağılım 3,7-19 yıl) idi. Hastaların sitolojik tanıları şu şekildeydi: \%1,9'u tanı dışı veya yetersiz, \%59,6'sı benign, önemi belirsiz atipi veya foliküler lezyon, \%2,4'ü foliküler neoplazm şüpheli, \%12,8'i malignite şüphesi, \%1,9'u malign idi. 59 hastaya cerrahi uygulandı. Otuz üç hastaya malignite tanısı konuldu. Benign ince iğne aspirasyon biyopsisi sonucu olan hastaların \%17,6'sında ameliyat olduklarında malignite saptandı. Önemi belirlenemeyen sitolojiye sahip atipi veya foliküler lezyonu olan hastaların $\% 44,4$ 'ünde malignite mevcuttu. İnce iğne aspirasyon biyopsisinin tanısal doğruluğu \%79 idi.

Sonuç: Bu çalışma, Türkiye'de çocuk ve ergenlerde tiroid nodüllerini araştıran ilk çok merkezli çalışmadır. Tiroid nodülü olan çocuklarda ince iğne aspirasyon biyopsisi tanıda önemli bir yere sahiptir ancak nodülün ultrasonografik özellikleri de dikkate alınmalıdır. Atipi veya önemi belirsiz foliküler lezyon bilinenden daha önemli olabilir.

\section{Introduction}

Although thyroid nodules are less frequent among children than adults, they are more likely to be malignant in children. Published case series suggest that the rate of malignancy in pediatric thyroid nodules ranges between $10-50 \%$ (1). The prevalence of thyroid nodules is estimated to be $0.2-5 \%$ in children and 19 $35 \%$ in adults (2). Risk factors for the development of thyroid nodules in children include family history of thyroid nodule or thyroid cancer, iodine deficiency, exposure to radiation, history of antecedent thyroid disease, increased serum thyrotropin (TSH), gender, race, age and various genetic syndromes (3-6). Although there is no definitive size for a nodule to be palpable, nodules larger than $1.5 \mathrm{~cm}$ are usually palpable. Changes in the size or structure of a nodule over time, the presence of tenderness and pain in the nodule, and attachment of the nodule to surrounding structures should be evaluated. Large, hard nodules that adhere to adjacent tissue are more likely to be associated with cancer (7).

Ultrasonography (USG) is a good method for determining the characteristics of the nodule. However, there are still no satisfactory data and, therefore, fine needle aspiration biopsy (FNAB) is needed for a definitive diagnosis. Ultasonographic characteristics of nodules including hypoechogenicity, solid structure, irregular margins, micro-calcifications and increased intra-nodular blood flow should all prompt FNAB (8).

FNAB is the best method to distinguish benign from malign nodules and diffuse goiter. Cytological examination is reported according to the Bethesda classification which will result in a reduction in the rate of unnecessary surgery (9). However, this classification also has limitations. The Bethesda classification consists of six categories and there may be diagnostic confusion in the third and fourth categories. Despite this, the American Thyroid Association (ATA) guidelines recommend the use of the Bethesda classification in both adults and children (10).

The aim of this study was to evaluate clinical, ultrasonographic, cytological and histopathological findings in children in whom FNAB was performed to investigate thyroid nodules and to compare the potential of USG findings and FNAB findings to detect malignancy.

\section{Materials and Methods}

\section{Patient Information}

The data of patients attending nine Turkish Pediatric Endocrinology Units between July 2002 and November 2019 because of thyroid nodule were retrospectively analyzed. Each thyroid nodule was evaluated with FNAB in all patients. Informed consent 
was obtained from the parents of the patients before FNAB. Patients without FNAB were not included in the study. Underlying thyroid diseases, demographical characteristics and physical examination of all children were recorded.

The study was approved by a local ethical committee.

\section{Laboratory Analysis}

Serum free thyroxine (fT4) and TSH levels were evaluated. Since the serum thyroglobulin level was not measured in all patients, it was not included in the analysis. The presence of thyroid autoantibodies was recorded.

\section{USG, FNAB and Histopathology}

USG examination recorded details of size, location, infrastructure, echostructure and vascularization characteristics of the nodule and the presence of micro-calcification and irregular margins were evaluated. The infrastructure was classified as solid, cystic or mixed. The echo-structure of the thyroid parenchyma was classified as hyperechoic, isoechoic, or hypoechoic. Vascularization characteristics were classified as avascular, internal vascularization, peripheral vascularization.

FNAB results were categorized according to the Bethesda classification system. These categories are: Bethesda 1 (non diagnostic or unsatisfactory); Bethesda 2 (benign); Bethesda 3 (atypia of undetermined significance [AUS] or follicular lesion of undetermined significance [FLUS]); Bethesda 4 (suspicious for follicular neoplasm or Hurtle cell neoplasm); Bethesda 5 (suspicious for malignancy); and Bethesda 6 (malign).

The histopathological results of the patients who underwent surgery were examined. Nodules diagnosed with thyroid cancer by histopathological examination were grouped as "malign" and other nodules as "benign".

\section{Statistical Analysis}

Data were statistically analyzed using SPSS, version 21.0 (SPSS, Chicago, IL, USA). Continuous variables are expressed as mean \pm standard deviation (SD). Categorical variables are presented as numbers (percentages). Continuous variables were compared with Mann-Whitney U test or Kruskal
Wallis test. Pearson chi-square tests were used to determine significant differences in proportions among categorical variables. A p value of $<0.05$ was considered statistically significant.

\section{Results}

\section{Patient Characteristics}

A total of 203 patients from nine centers were included in the study and $82.3 \%(\mathrm{n}=167)$ were female. Mean age was $14.06 \pm 2.26$ years, which ranged from 3.7 to 19 years. The most common presenting symptom was neck swelling in $67 \%(n=136)$. In $4.4 \%$ of the patients $(n=9)$, the nodule was detected while investigating the etiology of increased TSH. Difficulty in swallowing, neck pain and hoarseness were present in $1.3 \%(\mathrm{n}=3), 1.3 \%(\mathrm{n}=3)$ and $1 \%(\mathrm{n}=2)$ of the patients, respectively. The nodule was detected incidentally in other patients. More than a quarter (26.1\%; $n=53$ ) of the patients had a family history of thyroid disease. Most of the patients [78\% ( $n=50)]$ with histopathologically benign nodules had no family history of thyroid disease and this was significantly different from the rate of family history in patients with malign nodules $(\mathrm{p}=0.04)$. Nearly a third $(30.5 \%$; $\mathrm{n}=62$ ) of the patients had no goiter or palpable nodule while a further $30.5 \%(\mathrm{n}=62)$ had goiter, and $23.6 \%$ $(\mathrm{n}=48)$ had palpable nodule $(\mathrm{p}=0.18)$.

\section{Laboratory Analysis, FNAB and Histopathological Findings}

Hashimoto disease, diagnosed with antibody positivity and USG findings, was present in $17.2 \%$ $(n=35)$ of the patients. The FNAB results of these patients were: Bethesda $1 \mathrm{n}=2$; Bethesda $2 \mathrm{n}=25$; Bethesda $5 \mathrm{n}=5$; and Bethesda $6 \mathrm{n}=1$. Only patients with Bethesda 5 or 6 underwent surgery and these patients were diagnosed with papillary thyroid cancer (PTC). Cytology of the remaining two patients, who were not classified with Bethesda, was compatible with chronic lymphocytic thyroiditis. There was no medullary thyroid carcinoma.

The USG findings of 15 patients with Bethesda 2 were compatible with thyroiditis, without antibody positivity. The remaining 87 patients were followed as isolated nodules without an underlying disease. Two of these patients were diagnosed with non-thyroid cancer (Schwannoma and PTEN hamartoma). 
In the whole cohort, FNAB results of 189 patients were grouped by Bethesda classification. Other patients who could not be classified in these groups were reported as adenomatous nodule, cyst fluid only, thyroiditis, and chronic lymphocytic thyroiditis.

When biopsy subgroups were evaluated in terms of serum TSH and fT4 levels, there was no difference between the groups $(p=0.085, p=0.086)$ (Table 1$)$.

It was significantly more likely to identify nodules with microcalcifications in the group suspicious for malignancy $(p<0.001)$ when compared to the benign group who tended to have non-calcified nodules. While nodules with mixed echogenicity were generally found in the groups with benign results and those suspicious for malignancy, nodules with other echogenic features were mostly in the benign group or the AUS/FLUS group $(\mathrm{p}<0.001)$. There was no difference between the groups in terms of nodule margins $(\mathrm{p}=0.06)$, nor was there a difference between the groups in terms of nodule number, location and vascularization (Table 2).

In this population nodules with heterogeneous echogenicity were mostly observed in the suspicious for malignancy group (16.3\%) and the AUS/FLUS $(15.1 \%)$ group, while nodules with homogeneous echogenicity were prevalent in the benign group $(66 \%)(\mathrm{p}=0.02)$.

Surgery was performed in 29\% $(n=59)$ of the patients, some of whom had diffuse goiter with cystic/ solid nodules and benign cytology. However, there was still a risk for malignancy, hence the surgery.

Histopathological results for patients undergoing surgery were: multinodular goiter in $25.4 \%(n=15)$; follicular adenoma/adenomatoid nodule in $13.5 \%$ $(n=8)$; chronic lymphocytic thyroiditis in $3.3 \%(n=2)$; PTC in $33.2 \%(n=19)$; papillary microcarcinoma in $3.3 \%(\mathrm{n}=2)$; follicular variant PTC in $15.2 \%(\mathrm{n}=9)$; follicular thyroid cancer in $1.6 \%(\mathrm{n}=1)$; hamartoma in $1.6 \%(n=1)$; Schwannoma in $1.6 \%(n=1)$; and hyperfunctional cyst/adenoma in $1.6 \%(n=1)$. Serum TSH levels were significantly higher in the malignant group ( $\mathrm{p}=0.014)$.

Nodules smaller than $10 \mathrm{~mm}$ tended to be present in the benign group, although this was not significant. Cystic nodules tended to be present in the benign group, while solid nodules tended to be present in the malignant group $(\mathrm{p}<0.001)$. Nodules with microcalcifications were significantly more malignant $(\mathrm{p}<0.001)$. Iso-hypoechoic, hyperechoic and nodules with mixed echogenicity were mostly found in the malignant group; anechoic and hypoechoic nodules were mostly found in the benign group $(p<0.001)$ (Table 3).

Different features of the nodules were assessed in order to determine their usefulness in detecting malignancy. The sensitivity of nodule diameter to detect malignancy was $96.8 \%$ but specificity was only $15.3 \%$ while positive predictive value (PPV) was $58.4 \%$ and negative predictive value (NPV) was $80 \%$. Similarly, a solid nodule had a sensitivity of $84.3 \%$, specificity of $62.5 \%$, PPV of $75 \%$ and NPV of $75 \%$. When microcalcification was present, the sensitivity was 34.8 , specificity was $96 \%$, PPV was $91.6 \%$ and NPV was $53.3 \%$. There was a good correlation between cytological examination results reported as malign and/or suspicious for malignancy and nodules that were histologically reported as malignant $(\mathrm{p}<0.001)$ (Table 4). The malignancy rate was $16.2 \%$ for all patients.

When Bethesda 1-2 groups were classified as benign and 3-4-5-6 groups as malign, histopathological examination showed that nine patients were diagnosed as false positive and three patients were diagnosed as false negative. The sensitivity of FNAB in detecting pathology was $91 \%$, specificity was $65 \%$, PPV was $76 \%$, NPV was $85 \%$, and the diagnostic accuracy was $79 \%$.

Table 1. Cytology results

\begin{tabular}{|c|c|c|c|c|c|c|c|}
\hline & $\begin{array}{l}\text { Non- } \\
\text { diagnostic } \\
(n=14)\end{array}$ & $\begin{array}{l}\text { Benign } \\
(n=121)\end{array}$ & $\begin{array}{l}\text { AUS/FLUS } \\
(n=19)\end{array}$ & $\begin{array}{l}\text { SFN } \\
(n=5)\end{array}$ & $\begin{array}{l}\text { Suspicious for } \\
\text { malignancy } \\
(n=26)\end{array}$ & $\begin{array}{l}\text { Malign } \\
(n=4)\end{array}$ & $\mathrm{p}$ \\
\hline TSH (uIU/mL) & $5.1 \pm 3.75$ & $11.7 \pm 6.5$ & $2.08 \pm 0.3$ & $22.8 \pm 13.7$ & $13.8 \pm 11.4$ & $3.8 \pm 1.03$ & 0.085 \\
\hline fT4 (ng/dL) & $1.1 \pm 0.1$ & $1.1 \pm 0.02$ & $1.5 \pm 0.4$ & $0.9 \pm 0.2$ & $1.2 \pm 0.05$ & $1.3 \pm 0.3$ & 0.086 \\
\hline Nodule diameter $(\mathrm{mm})$ & $18.1 \pm 2.4$ & $19.1 \pm 0.9$ & $22.1 \pm 2.5$ & $28.7 \pm 4.01$ & $24.0 \pm 2.5$ & $13 \pm 3.3$ & 0.021 \\
\hline
\end{tabular}


Table 2. Evaluation of cytology results and ultrasonographic characteristics of nodules

\begin{tabular}{|c|c|c|c|c|c|c|c|}
\hline & Biopsy & & & & & & \\
\hline & $\begin{array}{l}\text { Non-diagnostic } \\
(\mathrm{n}=14)\end{array}$ & $\begin{array}{l}\text { Benign } \\
(\mathrm{n}=121)\end{array}$ & $\begin{array}{l}\text { AUS/FLUS } \\
(\mathrm{n}=19)\end{array}$ & $\begin{array}{l}\text { SFN } \\
(\mathrm{n}=5)\end{array}$ & $\begin{array}{l}\text { Suspicious for } \\
\text { malignancy } \\
(\mathrm{n}=26)\end{array}$ & $\begin{array}{l}\text { Malignant } \\
(\mathrm{n}=4)\end{array}$ & $\mathrm{p}$ \\
\hline \multicolumn{8}{|l|}{ Nodule diameter $(\mathrm{mm}) *$} \\
\hline$\geq 10(\mathrm{n}=22)$ & 0 & 86.4 & 9.1 & 0 & 0 & 4.5 & 0.14 \\
\hline$<10(\mathrm{n}=181)$ & 7.7 & 62.4 & 9.9 & 3.3 & 14.9 & 1.7 & \\
\hline \multicolumn{8}{|l|}{ Nodule parenchyma (\%) ** } \\
\hline Cystic (n=38) & 13.2 & 71.1 & 7.9 & 2.6 & 5.3 & 0 & 0.17 \\
\hline Solid $(\mathrm{n}=119)$ & 5 & 61.3 & 8.4 & 4.2 & 18.5 & 2.5 & \\
\hline Mixed $(n=42)$ & 7.1 & 71.4 & 14.3 & 0 & 4.8 & 2.4 & \\
\hline \multicolumn{8}{|l|}{ Nodule location $(\%) * *$} \\
\hline Bilateral $(n=43)$ & 2.3 & 67.4 & 11.6 & 2.3 & 16.3 & 0 & 0.95 \\
\hline Right lobe ( $\mathrm{n}=92$ ) & 8.7 & 63 & 9.8 & 4.3 & 13 & 1.1 & \\
\hline Left lobe $(n=42)$ & 7.1 & 66.7 & 9.5 & 2.4 & 11.9 & 2.4 & \\
\hline \multicolumn{8}{|l|}{ Nodule $(\%) * *$} \\
\hline Solitary $(n=133)$ & 8.3 & 64.7 & 8.3 & 3 & 12.8 & 3 & 0.53 \\
\hline Multiple ( $n=68)$ & 4.4 & 66.2 & 13.2 & 2.9 & 13.2 & 0 & \\
\hline \multicolumn{8}{|l|}{ Calcification $(\%) * *$} \\
\hline Calcification (-) $(\mathrm{n}=171)$ & 7.6 & 67.8 & 10.5 & 3.5 & 9.4 & 1.2 & $<0.001$ \\
\hline Microcalcification $(\mathrm{n}=30)$ & 3.3 & 50 & 6.7 & 0 & 33.3 & 6.7 & \\
\hline $\begin{array}{l}\text { Nodule echogenicity (\%) } \\
\text { Hypoechoic }(\mathrm{n}=39)\end{array}$ & 2.6 & 79.5 & 10.3 & 0 & 5.1 & 2.6 & $<0.001$ \\
\hline Isoechoic $(\mathrm{n}=34)$ & 14.7 & 44.1 & 23.5 & 0 & 17.6 & 0 & \\
\hline Iso-hyperechoic $(\mathrm{n}=13)$ & 0 & 53.8 & 30.8 & 7.7 & 0 & 7.7 & \\
\hline Hyperechoic $(\mathrm{n}=49)$ & 2 & 77.6 & 10.2 & 0 & 8.2 & 2 & \\
\hline Anechoic $(\mathrm{n}=10)$ & 30 & 50 & 0 & 10 & 10 & 0 & \\
\hline Mixed echogenicity $(\mathrm{n}=12)$ & 8.3 & 41.7 & 0 & 0 & 50 & 0 & \\
\hline \multicolumn{8}{|l|}{ Nodule Margins (\%)** } \\
\hline Regular Margin (n=176) & 7.4 & 67 & 10.2 & 3.4 & 10.2 & 1.7 & 0.06 \\
\hline Irregular Margins $(\mathrm{n}=25)$ & 4 & 52 & 8 & 0 & 32 & 4 & \\
\hline \multicolumn{8}{|l|}{ Vascularization $(\%) * *$} \\
\hline Avascular $(\mathrm{n}=159)$ & 6.3 & 67.9 & 8.8 & 2.5 & 12.6 & 1.9 & 0.12 \\
\hline $\begin{array}{l}\text { Both peripheral-internal } \\
(\mathrm{n}=12)\end{array}$ & 16.7 & 25 & 25 & 8.3 & 25 & 0 & \\
\hline $\begin{array}{l}\text { Internal vascularization } \\
(\mathrm{n}=12)\end{array}$ & 16.7 & 58.3 & 0 & 0 & 25 & 0 & \\
\hline $\begin{array}{l}\text { Peripheral vascularization } \\
(\mathrm{n}=18)\end{array}$ & 0 & 72.2 & 16.7 & 5.6 & 0 & 5.6 & \\
\hline
\end{tabular}


Table 3. Evaluation of histopathological results with serum TSH and ultrasonographic characteristics of the nodule

\begin{tabular}{|c|c|c|c|}
\hline & \multicolumn{2}{|c|}{ Histopathological Results } & \multirow[b]{2}{*}{$\mathrm{p}$} \\
\hline & $\begin{array}{l}\text { Benign } \\
(n=26)\end{array}$ & $\begin{array}{l}\text { Malignant } \\
(\mathrm{n}=33)\end{array}$ & \\
\hline TSH (uIU/mL)* & $1.694 \pm 1.407$ & $11.866 \pm 52.60$ & 0.014 \\
\hline \multicolumn{4}{|l|}{ Nodule diameter $(\mathrm{mm})(\%)^{* *}$} \\
\hline$<10(\mathrm{n}=5)$ & 80 & 20 & \multirow[t]{2}{*}{0.09} \\
\hline$\geq 10(\mathrm{n}=54)$ & 40.7 & 59.3 & \\
\hline \multicolumn{4}{|l|}{ Nodule Parenchyma $(\%) * *$} \\
\hline Cystic $(n=10)$ & 90 & 10 & \multirow[t]{3}{*}{$<0.01$} \\
\hline Solid $(n=35)$ & 22.9 & 77.1 & \\
\hline Mixed $(n=11)$ & 63.6 & 36.4 & \\
\hline \multicolumn{4}{|l|}{ Nodule location $(\%) * *$} \\
\hline Bilateral $(n=14)$ & 50 & 50 & \multirow[t]{3}{*}{0.52} \\
\hline Right lobe $(\mathrm{n}=26)$ & 34.6 & 65.4 & \\
\hline Left lobe $(\mathrm{n}=14)$ & 50 & 50 & \\
\hline \multicolumn{4}{|l|}{ Nodule number $(\%) * *$} \\
\hline Solitary $(\mathrm{n}=35)$ & 45.7 & 54.3 & \multirow[t]{2}{*}{0.72} \\
\hline Multiple (n=22) & 40.9 & 59.1 & \\
\hline \multicolumn{4}{|l|}{ Calcification $(\%)^{* *}$} \\
\hline No calcification ( $\mathrm{n}=45$ ) & 53.3 & 46.7 & \multirow[t]{2}{*}{$<0.01$} \\
\hline Microcalcification $(\mathrm{n}=12)$ & 8.3 & 91.7 & \\
\hline \multicolumn{4}{|l|}{$\operatorname{Echogenicity}(\%)^{* *}$} \\
\hline Iso-Hypoechoic $(\mathrm{n}=4)$ & 25 & 75 & \multirow[t]{6}{*}{$<0.01$} \\
\hline Hypoechoic $(n=9)$ & 66.7 & 33.3 & \\
\hline Hyperechoic $(\mathrm{n}=3)$ & 0 & 100 & \\
\hline Isoechoic(n=12) & 50 & 50 & \\
\hline Anechoic $(\mathrm{n}=4)$ & 100 & 0 & \\
\hline Mixed Echoic $(\mathrm{n}=7)$ & 0 & 100 & \\
\hline \multicolumn{4}{|l|}{ Nodule Margins $(\%) * *$} \\
\hline Regular Margins (n=45) & 48.9 & 51.1 & \multirow[t]{2}{*}{0.14} \\
\hline Irregular Margins $(\mathrm{n}=12)$ & 25 & 75 & \\
\hline \multicolumn{4}{|l|}{ Vascularization $(\%)^{* *}$} \\
\hline Avascular $(\mathrm{n}=42)$ & 42.9 & 57.1 & \multirow[t]{4}{*}{0.47} \\
\hline Both Peripheral-Internal (n=5) & 20 & 80 & \\
\hline Internal Vascularization $(\mathrm{n}=4)$ & 50 & 50 & \\
\hline Peripheral Vascularization $(n=6)$ & 66.7 & 33.3 & \\
\hline
\end{tabular}

\section{Discussion}

Although thyroid nodules are rare in childhood, the rate of malignancy is higher than in adults with rates ranging from $10 \%$ to $50 \%$ (1). In a recent Turkish study with 80 patients, the malignancy rate was reported as $38.8 \%$ (11). However, the malignancy rate was lower at $16.2 \%$ in our study although both of these rates fall within the range reported by Kirkland et al. (1). 
Table 4. Evaluation of histopathological results and cytological results

\begin{tabular}{lccl}
\hline \multicolumn{4}{l}{ Histopathological results } \\
\hline & $\begin{array}{l}\text { Benign } \\
(59)\end{array}$ & Malignant (33) & $\mathrm{p}$ \\
\hline FNAB (\%) & & & \\
$\begin{array}{l}\text { Non-diagnostic/ } \\
\text { Unsatisfactory }\end{array}$ & 100 & 0 & $<0.01$ \\
$\begin{array}{l}\text { Material (3) } \\
\text { Benign (17) }\end{array}$ & 82.4 & 17.6 & \\
AUS/FLUS (9) & 55.6 & 44.4 & \\
SFN (0) & 0 & 0 & \\
$\begin{array}{l}\text { Suspicious for } \\
\text { Malignancy (26) }\end{array}$ & 15.4 & 84.6 & \\
Malignant (3) & 0 & 100 & \\
Pearson Chi-square test & & &
\end{tabular}

Physical examination of a palpable nodule can provide some information about the malignancy risk. However, thyroid nodules are mostly impalpable. In our series, the incidence of palpable thyroid nodule was $23.6 \%$ but there was no association between biopsy results and palpability of the nodule.

Many studies report that increased TSH is an important risk factor for differentiated thyroid cancer in both children and adults (12-16). We found no association was found between TSH levels and FNAB results. However, TSH levels were significantly higher in the malignant group. This is consistent with the hypothesis that increased TSH can increase malignancy risk in thyroid nodules.

There are studies investigating the relationship between autoimmunity and malignancy. In a cohort of children and adolescents with Hashimoto thyroiditis, the prevalence of thyroid cancer was reported to be $3 \%$ (12). In our study, the prevalence of malignancy in patients with Hashimoto thyroiditis was $5.7 \%$. It is important to follow up patients with autoimmunity for the development of malignancy.

Ultrasonography is an important diagnostic tool to detect nodules that should be evaluated with FNAB. There are many studies investigating the relationship between ultrasonographic findings and biopsy findings. In a study conducted with 314 children, it was reported that the malignancy rate was high in solid, solitary, very hypoechoic nodules with irregular borders and calcification, when accompanied by multiple pathological lymph nodes. These authors did not find a significant difference between the groups in terms of characteristics of vascularization (17). Similarly, there was no relationship between vascularization and malignancy in our cohort, which is consistent with the literature.

In our study, calcified nodules were mostly present in the suspicious for malignancy group, while nodules with mixed echogenicity were mostly in the benign or in the suspicious for malignancy groups. This suggests that, with the exception of calcifications, the features of the nodule did not help to identify those requiring examination with FNAB. However, there was significant overlap between histopathological results and USG findings. In contrast to adult studies (18), in children, the risk of malignancy increases as the size of the nodule increases (17).

Micro-calcified nodules and solid nodules were mostly present in the malignant group. However, contrary to the literature (17), hypoechoic nodules were mostly included in the benign group. Irregular nodular margins suggest malignancy $(11,17)$. However, we did not find such a relationship in our study. The SFN group had the highest mean diameter, while the malignant group had the lowest mean diameter. Nodule size (diameter) was sensitive but not specific in our cohort, possibly because many patients in the benign group had nodules of greater than $10 \mathrm{~mm}$ in diameter.

The vast majority of the nodules reported as suspicious for malignancy/or malign by FNAB were found to be in the malignant group following histopathological examination. This is in keeping with the results of a meta-analysis that showed that FNAB was a very sensitive tool to distinguish between benign and malignant nodules (19). ATA guidelines still suggest that FNAB is an important diagnostic tool to decide on surgery (10). In the last ATA guideline, the risk of malignancy for the AUS/FLUS category was $5-15 \%$, and lobectomy was recommended for this group. It was reported that this rate was $35 \%$ in adults, but the risk was reduced if not supported by ultrasonographic findings (20). However, this category is a diagnostic dilemma. Suspicious findings on USG may be supportive for a decision to proceed to surgery in patients AUS/FLUS cytology. In our study, 44.4\% of patients in the AUS/FLUS cytology group were found to have malignant nodules on histopathological examination. This was a remarkably high rate and 
these results suggest that the risk of malignancy is high in indeterminate cytology in a pediatric population. However, because of the multicenter nature of the study, inconsistency in ultrasonographic and pathological assessments may explain some of this finding. Lobectomy for nodules with AUS/FLUS cytology seems to be an appropriate recommendation, given the results reported here.

Inconsistency in ultrasonographic evaluations increases the importance of FNAB in distinguishing between benign and malignant nodules. In our study, nine patients had false positivite and three patients had false negative findings based on Bethesda categories. FNAB was sensitive, specific and accurate with good PPV and NPV. However, the rate of malignancy in our patients with AUS/FLUS cytology was the highest rate reported to date. In addition, the detection of malignancy in $17.6 \%$ of patients with benign FNAB results indicates that FNAB should definitely be evaluated together with other diagnostic tests. When nodules were found to be malignant by histopathological evaluation, but whose FNAB results were benign, the nodule size was $>40 \mathrm{~mm}$ in size. This indicates that even if the FNAB result is benign, other features of the nodule should be considered.

USG is a good diagnostic tool for follow-up of thyroid nodules and identifying the ones that require FNAB examination. However, USG is very much operator dependent and therefore may be insufficient in all patients. Our findings suggest that USG can be used as a diagnostic tool, but FNAB should be performed even for the slightest suspicion of malignancy. FNAB is the most important method for determining which nodules require surgery. AS has been previously reported, FNAB in this multicenter study had high accuracy in detecting malignancy. However, some nodules that were reported as benign by FNAB examination were not always benign. We therefore suggest that more accurate results can be obtained when the findings from USG and FNAB are combined.

\section{Study Limitations}

Our study has some limitations which include the lack of data in some patients about previous history of radiotherapy.

\section{Conclusion}

In conclusion, this study included the largest number of cases of pediatric thyroid nodules in Turkey. In addition, it was the first multicenter study investigating thyroid nodules in children and adolescents in Turkey. The rate of malignancy in patients with AUS/FLUS cytology was the highest rate reported to date. These new finding may contribute to making a surgical decision.

\section{Ethics}

Ethics Committee Approval: The study was approved by a local ethical committee.

Conflict of Interest: No conflict of interest was declared by the authors.

Financial Disclosure: The authors declared that this study received no financial support.

\section{References}

1. Kirkland RT, Kirkland JL, Rosenberg HS, Harberg FJ, Librik L, Clayton GW. Solitary thyroid nodules in 30 children and report of a child with a thyroid abscess. Pediatrics 1973;51:85

2. Bauer AJ, Francis GL. Evaluation and management of thyroid nodules in children. Curr Opin Pediatr 2016;28:536-44.

3. Giannoula E, Iakovou I, Chatzipavlidou V. Risk factors and the progression of thyroid malignancies. Hell $\mathrm{J}$ Nucl Med 2015;18:275-84.

4. Giannoula E, Gkantaifi A, Iakovou I. Radiation treatment of head and neck carcinomas as a risk factor for thyroid carcinomas. Hell J Nucl Med 2016;19:65-74.

5. Xing M. Molecular pathogenesis and mechanisms of thyroid cancer. Nat Rev Cancer 2013;13:184-99.

6. Esen I, Bayramoglu E, Yıldız M., Aydın M, Karakılıc, Ozturhan $\mathrm{E}$ et al. Management of Thyrotoxicosis in Children and Adolescents:A Turkish Multi-center Experience. J Clin Res Pediatr Endocrinol 2019;11:164-72.

7. Gardner DG, Shoback D. Hormones and hormone action. In:Green Spans Basic and Clinical Endocrinology, 9th ed.; Yale Journal of Biology and Medicine: New York, NY, USA, 2012.

8. Jatana KR, Zimmerman D. Pediatric thyroid nodules and malignancy. Otolaryngologic Clinics of North America 2015;48:47-8.

9. CibasES, Ali SZ. NCI Thyroid FNA State of the Science Conference. The Bethesda System for Reporting Thyroid Cytopathology. Am J Clin Patho 2009;132:658-65.

10. Francis GL, Waguespack SG, Bauer AJ, Angelos P, Benvenga S, Cerutti JM et al. Management Guidelines for Children with Thyroid Nodules and Differentiated Thyroid Cancer. Thyroid 2015;25:716-59.

11. Kardelen AD, Yilmaz C, Poyrazoglu S, Tunca F, Bayramoglu Z, Bas F et al. The Role of Thyroid Fine-Needle Aspiration Cytology in the Treatment and Follow-up of thyroid Nodules in The Pediatric Population, Acta Endocrinol (Buchar) 2019;15:333-41. 
12. Corrias A, Cassio A, Weber G, Mussa A, Wasniewska M, Rapa A et al. Thyroid nodules and cancer in children and adolescents affected by autoimmune thyroiditis. Arch Pediatr Adolesc Med 2008;162:526-31.

13. Mussa A, Salerno MC, Bona G, Wasniewska M, Segni M, Cassio A et al. Serum thyrotropin concentration in children with isolated thyroid nodules. J Pediatr 2013;163:1465-70.

14. Fiore E, Rago T, Latrofa F, Provenzale MA, Piaggi P, Delitala A at all. Hashimoto's thyroiditis is associated with papillary thyroid carcinoma:role of TSH and of treatment with L-thyroxine. Endocr Relat Cancer 2011;18:429-37.

15. Boi F, Minerba L, Lai ML, Marziani B, Figus B, Spanu F et al. Botht hyroid autoimmunity and increased serum TSH are independent risk factors for malignancy in patients witht hyroid nodules. J Endocrinol Investing 2013;36:313-20.

16. Kim HK, Yoon JH, Kim SJ, Cho JS, Kweon SS, Kang HC. Higher TSH level is a risk factor for differentiated thyroid cancer. Clin Endocrinol (Oxf) 2013;78:472-7.
17. Danielle M. Richman, Carol B. Benson, Peter M. Doubilet, Hope E. Peteres, Stephen A. Huang, Elizabeth ASCH et al. Thyroid Nodules in Pediatric Patients: Sonographic Characteristics and Likelihood of Cancer, Radiology 2018;288:591-9

18. Frates MC, Benson CB, Doubilet PM, Kunreuther E, Contreras $\mathrm{M}$, Cibas ES et al. Prevalence and distribution of carcinoma in patients with solitary and multiple thyroid nodules on sonography. J Clin Endocrinol Metab 2006;91:3411-7.

19. Lai SW, Roberts DJ, Rabi DM, Winston KY. Diagnostic accuracy of fine needle aspiration biopsy for detection of malignancy in pediatric thyroid nodules:prtocol for a systematic review and meta-analysis. Syst Rev 2015;24:120.

20. Ryu YJ, Jung YS, Yoon HC, Hwang MJ, Shin SH, Cho JS et al. Atypia of undetermined significance on thyroid fine needle aspiration:surgical Outcomeand risk factors for malignancy. Annals of Surgical Treatment and Research 2014;86:109-14. 